Iqtishodiyah: Jurnal Ekonomi dan Bisnis Islam

Vol. 8 No. 1 (2022) Hal. 1-17, ISSN (Print): 2460-5956 ISSN (Online): 2548-5911

DOI: $10.36835 /$ iqtishodiyah.v7i2.768

\title{
ANTROPOLOGI EKONOMI
}

\author{
Abd. Ghafur \\ Universitas Islam Zainul Hasan Genggong Probolinggo \\ Jl. PB. Sudirman No. 360 Semampir Kraksaan Probolinggo \\ Abdghafur1987@gmail.com
}

\begin{abstract}
Economic anthropology has a distinctive tendency in studying economic problems, paying a lot of attention to various symptoms of exchange that do not involve the use of money as an exchange mechanism. Economic anthropology studies how society provides material goods and services. As long as it is provided people will be in touch with each other. several points that cannot be separated from economic anthropology, namely about livelihoods, work, production, consumption, distribution, market trade, money and barter, credit and debt, globalization, socialism, moral and household economics, even in economic anthropology to see the structure and behavior economics uses three different paradigms
\end{abstract}

Keywords: Economics, Anthropology

\begin{abstract}
ABSTRAK
Antropogi ekonomi mempunyai kecenderungan yang khas dalam mengkaji masalah perekonomian banyak menaruh perhatian terhadap berbagai gejala pertukaran yang tidak melibatkan penggunaan uang sebagai mekanisme pertukaran. Antrpologi Ekonomi mempejalari bagaimana masyarakat menyediakan barang dan jasa material. Selama penyediannya orang akan berhubungan satu sama yang lain. beberpa poin yang tidak bisa lepas dari antropologi ekonomi yaitu tentang pencaharian, kerja, produksi, konsumsi, distribusi, perdagangan pasar, uang dan barter, kredit dan hutang, globalisasi, sosialisme, ekonomi moral dan rumha tangga bahkan dalam antropologi ekonomi untuk melihat struktur dan peilaku ekonomi menggunakan tiga pradigma yang berbeda

Kata Kunci : Ekonomi,Antropologi
\end{abstract}




\section{PENDAHULUAN}

Antropologi diangap sebagai disiplin ilmu yang relative baru karena perkembangan utamanya terutama terjadi pada abad kesembilan belas dan kedua puluh. Pdahal di Prancis dan Jerman, disipilin ini mendapat momentum pada abad ketujuh belas dan kedelapan belasdenga nama yang berbeda, seperti etnologi, Volkskunde dll. Kata antropologi berasal dari bahasa Yunani, yaitu'anthropos berarti manusia dan 'logos' berarti ilmu pengetahuan, dan dengan demikian, antropologi mewakili ilmu tentang manusia. Tugas utama antropologi adalah studi tentang manusia-yaitu untuk memunkinkan kita memahami diri kita sendiri melalui pemahaman budaya lain.Nurazzura \& Dewan Mahbub. 2014

Antropologi sebagai ilmu membahas segala hal tentang eksistensi manusia. Disiplin ini sangat unik, di satu sisi mengkaji eksistensi manusia secara biologis, namun secara bersamaan mempelajari aspek kebudayaannya dalam konteks yang luas. Jacob (2006: v-vii) menegaskan bahwa manusia akan selalu memik segala sesuatu, mencari, merancang, mencoba, dan mengubah, melahirkan kebudayaan serta meningkatkan peradabannya untuk men' menyelesaikan semua masalah dalam kehidupannya. Swasono (2 mengelompokkan antropologi dominan sebagai cabang ilmu-ilmu memberikan peran penting bagi pembangunan bangsa Indonesia.

Istilah “ Antropologi ekonomi” pertama kali digunakan pada tahuan 1920 an. Ini menggantikan terminology sebelumnya seperti “ekonomi primitif”. Setelah Melville Heskovts menggunakannya sebagai judul ringkasan pada tahun 1940. Edisi kedua karya Herskovits memiliki penekanan yang sangat berbeda dari aslinya, yang telah menarik kritik tajam dari ekonomi Frank Kningt. Kontroversi teoritis memuncak selama debat formalis -substantivis berikitnya, yang dapat dilihat secara retrospektif sebagai zaman keemasan unttuk bidang tersebut. Sementara "formalis" sprit Firth menyatakan bahwa aksioma ekonomi berlaku di mana-mana, karena semua pengambilan keputusan adalah tentang pengabilan pilihan rasional untuk mengalokasikan sumber daya yang langka, lawan mereka bersikeras bahwa jenis masyarakat yang berbeda menunjukkan bentuk integrasi ekoomi yang khas. Pemimpin aliran substantivis adalah sejarawan ekonomi karl polayi, yang membedakan dua arti kata "ekonomi” baginya, sementara memaksimalkan hubungan sarana tujuan yang merupakan fenomena yang universal. Bentuk lain, seperti timbal balik, redistribusi, dan rumah tangga lebih penting menurut polayi, pasar pembentuk harga hanya menjadi dominan setelah revulusi industri.hal ini menyebkan, yang paling terkenal di inggris abad ke Sembilan belas, pada "pelepasan ekonomi" dari masyarakat, suatu kondisi potologis yang hanya dapat diperbaiki oleh transformasi.Polayi dipengaruhi oleh analisi Karl Marx tentang eksploitasi kapitalis tetapi dia mengkritik materialism historis karena determinasi ekonomi dan lebih menekankan pada ekspnsi komodintas daripada hubungan produksi kapitalis. 
Perdebatan antara Kaum formalis dan substantivis menimbulkan polemic selama lebih dari satu decade. Polayi dan beberapa pengikutnya (terutama George Dalton) tampaknya siap untuk mengaku bahwa kaum substantivis hanya memiliki sedikit kontribusi untuk studi ekonomi industri modern. Karena pertukrana pasar adalah bentuk integasi yang dominan, perekonomian ini dapat diserahkan kepada para ekonom. Premisnya adalah bahwa semua aktifitas ekonomi, bahkan yang sepenuhnya bergantung pada teknologi digital baru, berlangsung dalam konteks social budaya tertentu. Sebaliknya, secara umum, diterima bahwa setidaknya beberpa teknik ekonom arus utama dapat diterapkan secara produktif pada masyarakat pra industri dan bahkan pada masyarakat yang tidak menghasilkan uang.Chris Haan. 2018

Antropologi ekonomi mempunyai kecenderungan yang khas dalam mengkaji masalah perekonomian yaitu banyak menaruh perhatian terhadap berbagai gejala pertukaran yang tidak melibatkan penggunaan uang scbagai mekanisme pertukaran. Berbagai gejala pertukaran tersebut sering dikenal dengan nama resiprositas dan redistribusi. Kecenderungan disiplin antropologi ekonomi seperti itu berkaitan dengan orientasi studi antropologi yang banyak menaruh perhatian pada masyarakat-masyarakat di luar Eropa. Ketika awal perkembangan disiplin antropologi ekonomi, umumnya gejala-gejala pertukaran yang terjadi dalam perekonomian di masyarakatmasyarakat di luar Eropa tersebut tidak menggunakan mekanisme uang sebagaimana seperti terjadi di Eropa.

Kecenderungan antropologi ekonomi banyak menaruh perhatian pada gejala pertukaran resiprositas dan redistribusi disertai pula dengan cara kerja disiplin ini yang berbeda dengan disiplin ilmu ekonomi. Dalam melihat gejala pertukaran, antropologi ekonomi tidak hanya melihat gejala tersebut sebagai gejala ekonomi semata, melainkan sebagai gejala kebudayaan yang keberadaannya berdimensi luas, tidak sekedar berdimensi ekonomi, tetapi juga agama, teknologi, ekologi, politik dan organisasi sosial.

Meskipun antropologi menempatkan gejala pertukaran sebagai persoalan yang berdimensi luas, tetapi disiplin ini kurang menaruh perhatian terhadap pertukaran yang menggunakan mekanisme uang, sebagaimana yang dan menjadi ciri dari sistem ekonomi pasar. Ilmu ekonomi, sebaliknya, paling banyak berurusan dengan masalah pertukaran dalam e onomi pasar. Walaupun demikian, ilmu ekonomi mengabaikan variabel-variabel sosial budaya dalam menganalisis permasalahan ekonomi (Dalton, 95)

Keterlibatan antropologi ekonomi dalam mengkaji masalah pertukaran dalam ekonomi pasar dirasa perlu sejalan dengan kenyataan bahwa transformasi ekonomi tradisional menuju sistem ekonomi modern sedang melanda di berbagai tempat, sejak berkembangnya penjajahan sampai masa globalisasi sekarang ini. Pertukaran resiprositas yang menjadi ciri pertukaran dalam 
perekonomian tradisional mengalami perubahan dan berhadapan dengan sistem Pertukran komersial.Sistem pertukaran mempunyai peranan yang penting dalam memenuhi kebutuhan masyarakat terhadap barang dan jasa. Kesejahteraan hidup warga masyarakat di samping dipengaruhi oleh sistem produksi yang dipakai juga sistem pertukaran yang berlaku.

Dalam kepustakaan antropologi ekonomi, baik yang berupa majalah, laporan penelitian maupun buku teksbook, istilah pertukaran kadang-kadang disamakan dengan istilah distribusi, namun Cook (1973) membedakan kedua istilah tersebut. Menurut Cook (1973: 823) distribusi merupakan suatu konsep yang berhubungan dengan aspek-aspek tentang pemberian imbalan yang diberikan kepada individu-individu atau pihak-pihak karena mereka telah mengorbankan faktorfaktor produksi yang dimiliki untuk proses produksi, Batasan ini mengandung arti bahwa dalam distribusi, proses, pemindahan barang atau jasa terjadi dalam unit produksi (lembaga produksi), dan terjadi antara lembaga produksi dengan individu yang menjadi anggota maupun antar individu-individu tersebut. Adapun pertukaran merupakan konsep yang berhubungan dengan aspek-aspek tentang pengubahan barang atau jasa tertentu dari individu-individu atau kelompokkelompok, dan pengubahan ini dilakukan dengan cara memindahkan barang atau jasa kepada individu-individu atau kelompok-kelompok lain guna mendapatkan barang atau jasa yang dibutuhkan.

Ahli antropologi ekonomi melihat bahwa sistem perekonomian mrerupakan produk dari suatu sistem sosial masyarakat. Sistem perekonomuan pasar merupakan produk masyarakat industri. Namun demikian, Organisasi perekonomian ini berjalan tanpa kontrol dari sistem sosial masyarakat. Perekonomian ini berfungsi tanpa campurtangari sistem sosial yang berlaku sehingga para ahli ekonomi tidak perlu memasukkan aspekaspek organisasi kemasyarakatan yang lebih luas di dalam mengkaji suatu perekonomian (LeClair dan Schneider, 1968 : 7). Sebaliknya kajian antrpologi ekonomi menemukan adanya integrasi yang rapat antara institusi ekonomi dengan institusi kemasyarakatan. Kondisi seperti.ini membuat satu hal yang tidak mungkin bagi mereka untuk melukiskan fenomena ekonomi tanpa pada waktu yang sama menunjukkan aspek-aspek sosiokultural yang terkait (Dalton, $1961: 17$ ).

\section{TINJAUAN TEORITIS}

\section{Pengertian Antropologi}

Antropologi adalah suatu ilmu yang memahami sifat-sifat semua jenis manusia secara lebih komprehensi Williiam A. Haviland, terj. RG Soekarjo, 1988: 3 di kutip Tanrani mengeatkan Antropologi pertama kali dipergunakan oleh kaum Misionaris dalam rangka penyebaran agama Nasrani dan bersamaan dengan itu pula berlangsung sistem 
penjajahan terhadap negara-negara di luar Eropa. Pada era dewasa ini, antropologi dipergunakan sebagai suatu hal untuk kepentingan kemanusiaan yang lebih luas. Studi antropologi selain untuk kepentingan pengembangan ilmu itu sendiri, di negara-negara yang masuk dalam kategori Negara ketiga (Negara berkembang) sangat urgen sebagai "pisau analisis" untuk pengambilan kebijakan (policy) dalam rangka pembangunan dan pengembangan masyarakat.

Sebagai suatu disiplin ilmu yang cakupan studinya cukup luas, maka tidak ada seorang ahli antropologi yang mampu menelaah dan menguasai antropologi secara sempurna dan global. Sehingga, antropologi terfregmentasi menjadi beberapa bagian yang masing-masing ahli antropologi mengkhususkan dirinya pada spesialisasi bidangnya masing-masing. Pada dataran ini, antropologi menjadi amat plural, sesuai dengan perkembangan ahli-ahli antropologi dalam mengarahkan studinya untuk lebih memahami sifat-sifat dan hajat hidup manusia secara lebih komprehensif. Dan hubungan dengan ini pula, ada bermacam-macam antropologi seperti antropologi ekonomi, antropologi politik, antropologi kebudayaan, antropologi agama, antropologi pendidikan, antropologi perkotaan, dan lain sebagainya.

2. Pengertian Ekonomi

kata "ekonomi" berasal dari bahasa Yunani oikos, yang menunjukkan sebuah perkebunan berbasis rumah. Aristoteles, yang memiliki oikos seperti itu , mengontraskan swadaya yang teratur dengan ancaman yang ditimbulkan oleh perdagangan pasar. Mengingat etimologi ini, sungguh ironis bahwa ekonomi modern telah dikaitkan dengan dominasi yang terakhir. Jika ekonomi antropologi disamakan dengan berfilsafat lintas budaya tentang kehidupan manusia di dalam luas akal, maka Aristoteles layak untuk dapat diakui sebagai seorang pendiri ayah. Itu Akar spesialisasi ini paling sering dilacak pada ekspansi kerajaan kolonial Eropa , terutama sejak abad kedelapan belas dan seterusnya. Bentuk ekonomi "lain" yang didokumentasikan oleh ekspedisi ilmiah, tetapi juga oleh misionaris dan petualang lainnya , di seluruh daratan Eurasia serta di kerajaan luar negeri, pada awalnya berfungsi sebagai dasar untuk teori Pencerahan tentang tahaptahap evolusi. Ini berlanjut sepanjang yang kesembilan belas abad, oleh para akhir dari yang sistematis perhatian dibayar untuk tenaga kerja dan budaya material. Namun, sampai generasi Franz Boas dan Bronislaw Malinowski menetapkan standar untuk jangka panjang lapangan penelitian, yang ekonomi tidak dipandang sebagai objek utama dari teori antropologi dan tidak ada keterlibatan dengan para ekonom. (Chris Hann) 
3. Sejarah antropologi ekonomi dan ilmu ekonomi

Pada awalnya ahli antropologi hnya memerhatikan data ekonomi sebagai bagian dari data etnografi. Segabian dari data yang mereka sebut sebagai data ekonomi yang sulit dipisahkan dari data non ekonomi. langkah-langkah yang mencoba memishkan data ekonomi menjadi kajian tersendiri, atau mencoba mengkaji etnografi dengan memfokuskan pada bidang ekonomi mulai dirintis pada awal abad 20, ketika teori-teori ekonomi terjadi telah berkembang.

Perkembangan antropologi selanjutnya tidak dapat dipisahkan dari pengaruh ilmu ekonomi. dalam arti, para ahli antropologi tidak menutup mata terhadap teori, konsep maupun metode yang di pakai para ekonom dalam mengkaji masalah-masalah ekonomi. langkah itu dimulai sejak para ahli antropologi menaruh perhatian terhadap gejala ekonomi pada masayarakat sedrehana maupun peasent. Karena ketika itu belum ada teori atau konsep yang mengkaji masalah ekonomi, sebaliknya ilmu ekonomi telah berkembang maju membangun teori, konsep dan hokum-hukum ekonomi. dengan manaruh perhatian terhadap ilmu ekonomi, maka secara tradisional ahli antropologi ekonomi mempunyai pengetahuan seperti harga, sewa, bunga, investasi , dan sebagainya.

Dalam antropologi ekonomi terdapat dua pendekatan (formalis dan substantif) tekait berlakunya teori dan konsep serta metode untuk mengkaji fenomena dalam perekonomian primitive dan peasent.

Ahli antroologi ekonomi menghadap fenomena ekonomi dalam masyaarkat sederhana terintgritasi dengan sistem social dan budaya masyarakat. (Dalton: 12) menekankan bahwa situasi mempengaruhi kajian antropologi ekonomi sehingga definisi Bohannan (1958) tepat diperhatikan oleh ahli antropologi:

Pada dasarnya, antropologi tidak mengajukan perranyaan yang sama dengan ekonomi. Bisnis antropologi bukanlah ekonomi; ini lebih merupakan sesuatu yang disebut "etno ekonomi" sebuah pernyataan dari katagori pemikiran dan bahasa, gagasan, prinsip tindakan, yang dalam hal ini seseorang melembagakan bisnis untuk mencari nafkah. Untuk tugas antropologi menjelaskan bagaimana sesornag mencari nafkah, kemudian mengklasifikasikan metode tersebut, dan bberteori tentang cara mereka terkait dengan atribut budaya atau social lainnya.

Definisi Bohannan tersebut melihat bahwa apa yang dimkasud dengan fenomena ekonomi lebih menunjuk kepada sistem budaya yang mendasari perilkau ekonomi yang tampak. Dengan memperhatikan aspek sistem budaya tesebut, maka aspek manusia sebagai pelaku ekonomi menjadi Nampak dalam kajian, kajian antropologi ekonomi meliputipula 
mempeljari peran-peran individu di dalam kegiatan ekonomi, dan termasuk individuindividu dalam sistem ekonomi industry (Frakenberg, $1975: 55$ ).

Ahli antrpologi ekonomi melihat bahwa sistem perekonoian merupakan produk dari suatu sistem social masayarakat. Sistem perekonomian pasar merupakan produk masyarakat industry. Namun demikian, organisasai perekonomian ini berjalan tampa control dari sistem social masyarakat. Perekonomian ini berfungsi tampa campurtangan sistem social yang berlaku sehingga para ahli ekonomi tidak perlu memasukkan aspek aspek organisasi kemasyarakatan yang lebih luas di dalam mengkaji suatu perekonomia. Sebaliknya kajian antropologi ekonomi menemukan adanya integrasi yang rapat antara institusi ekonomi dengan institusi kemasayarakan. Hal yang seperti ini membuat suatu hal yang tidak mungkin bagi mereka untuk melukiskan fenomena ekonomi tampa pada waktu yang sama menunjukkan aspek-aspek social kultural yang terkait (Dalton, 1961: 17).

4. Definisi Antropology Ekonomi

Tantangan pertama yang ingin dilihat pada sejarah antropology ekonomi adalah menemukan definisi yang berguna tentang bidang tersebut. Menurut Dalton dikutip oleh Andres mberpendapat bahwa bahwa penelitian dalam antropologi ekonomi bercirikan :

a. Kerja lapangan individu

b. Focus pada ekonomi kecil (masyarakat)

c. Dan pertmbangan sejarah. Menurut Dalton, ekonomi terdiri dari serangkaian topic yang berbeda, seperti struktur dan kinerja pra-kolonial, pra-industri,colonial, dan pascakolonial, dan ekonomi petani.

Menurut Dalton dikuti Andres mengatakan, antropologi ekonomi juga dpat didefinisikan serangkain topik yang ditulis para sarjana yang menyebut diri mereka “Antropologi ekonomi, misalnya anggota Socienti of Eco nomic Anhtropology (SEA). Dalam pertemuan perdana Society of economic 1982 para peserta membahas topok-topok berikut, antara lain: (1) sejarah Mexico pra-Hispanik, (2) Evolusi Oaxaca pra-Hispanik (3) kontribusi Mark pada antropology ekonomi (4) Pemikiran perdebatan formalis Vs substantivis karl Polayi (5) masalah analisis pengambilan keputusan dankopleksitas dalam teori peemainan dan model pemprograman linier (6) pembangunan yang tidak merata (7) Asumsi inti ekonomi pembangaunan yang biasanya tidak memperhitungkan peran politik dan mengandalkan definisi rasionalitas yang sempit (8) menambahkan elemen soial dan budaya kedalama anaalisi biaya manfaat. 
Ekonomi antropologi sebagai persimpangan antropologi dan ekonomi. secara garfish akan terlihat seprti irisan antara dua himpunan (ekonomi dan antropologi). Definisi ini mencakup penggunanaa alat-alat ekonomi untuk menganalisis topic-topik yang dipelajari secara tradisonal dalam antropologi, dan menggunakan alat-alat antropologi untuk mempejarai variable-variabel ekonomi tradisional. Artinya para ekonomi yang telah mempejarai budaya dan nilai-nilai di anggap sebagai antropologi ekonomi untuk tujuan analisis. Andres. 2010

5. Antropologi Ekonomi: Deskripsi dan Analisis

Literatur antropologi ekonomi sering menampilkan dikotomi:deskrpsi yang sangat baik tentang organisasi ekonomi, proses, nilai, dan teknologi, dikombinasikan dengan analisi dan generalisasi teoritis yang tidak memadai. Namun dikotomi tersebut mencerminkan persiapan yang dikembangkan dari para antropologi. Deskripsi data yang tepat di mana antropologi membenamkan dirinya adalah fitur yang membedakan profesi. Analisi teoritis, bagaimanapun, adalah salah satu langkah menjadi data;dan seperti prakonsepsi ekonomi dan ekonomi budaya antropologi sendiri yang mengaburkan membuat analisis teoritis ekonomi primitif menjadi lebih sulit dan kurang berhasil.

Untuk antropologi ekonomi, hanya makna yang substantive dari ekonomi yang relevan. Untuk komonitas primitif manapun, seorang hanyna dapat mengasumsikan keberadaan semacam aparatur institusional yang melalui barang-barang material diperoleh dan didistribuskan. Seorang tidak dapat mengasumsikan secara universal keberdaan lembaga ekonomi khusus seprti yang membedakan ekonomi pasar. Bukan penghematan perhitungan yang disebabkan oleh "kelangkaan" yang besifat universal, melainkan kebutuhan untuk penyediaan barang-barang material yang terstruktur.George Dalton, 1961

\section{PEMBAHASAN}

1. Antropologi Ekonomi

Antropologi Ekonomi mempejalari bagaimana masyarakat menyediakan barang dan jasa material. Selama penyediannya orang akan berhubungan satu sama yang lain (Morgan \& Qin.)

\section{a. Definisi}

Antropologi Ekonomi pada Awalnya berfokus pada kehidupan Ekonomi Masyarakat Primitf, di mana banyak elemen yang ada dalam ekonomi barat (seprti uang, sistem pasar) tidak ada. Pengamatan langsung terhadap masyarakat non-kapitalis melalui kerja lapangan etnografi menghasilkan hasil yang mengesankan dan informasi yang kaya 
secara kontektual tentang kegiatan ekonomi di seluruh dunia. Cara para antropologi bereaksi terhadap konfrontasi ini bagaimana mereka mengtasinya secara teoritis, menghasilkan sebagian besar perdebatan dalam antropologi ekonomi.

b. Debat Intelaktual

Perdebatan utama dalam anttropologi ekonomi telah berpusat di sekitar (a) penerapan universal kagori analisis yang dihasilkan Barat (b) Pertanyaan tentang nilai (c) pertanyaan tentang sejarah dan kebutuhan antra pemerintahan, dan (d) bobot budaya (makna) dalam proses ekonomi.

1) Katagori Analis Barat

Perdebatan utama terjadi antara para antropologi yang menganggap bahwa dalildalil ekonomi marjinalis, yaitu, alokasi rasional (mengoptimalkan) sumber daya (langka). Para antropologi yang mengikuti polayiberfikir bahwa tindakan rasional sehubungan dengan pengambilan keptusan ekonomo hanya berlaku dalam konteks ekonomi pasar barat, dan bahwa definisi ekonomi yang sebenarnya harus bermakna dalam masyarakat manapun.

2) Pertanyaan tentang nilai

Pertanyaan tentang nilai adalah fungsi sebagai pertukran kebutuhan untuk mencapai kesetaran melalui perbanidngan. Beberapa aspek nilai telah menjadi sumber perdebatan terus menerus dalam antropologi.

3) Budaya

Aspek budaya telah diperhitungkan dalam antropologi ekonomi terutama kontes dimana kegaiatan material terjadi.

c. Konsep danTeori

1) Produksi secara umum dipahami sebagai transformasi manusia dari materi, melaluikerja menjadi beberapa barang yang bergunadan dapat dikonsumsi. Disebagain besar masyarakt, proses produksi memerlukan penggunaan teknologi yang kompleks dan desain proses kerja yang kompetitif. Pengetahuan tentang keteramplan yang diperlukan utnuk menggunkan teknologi tertentu dan kordinasi seluruh proses merupakan asset control penting yang umumnya didistribusikan secara tidak mereta diantara mereka yang berpartisiapsi dalam produksi.ini telah memberi kesempatan para antropologi untuk menganalisis interaksi kecil yang terjadi dianatar mereka yang berpartisipasi dalam kerja yang komplit. 
2) Distribusi dan sirkulas

Konsep distribusi mengacu pada alokasi barang antara individu atau kelompok yang berbeda, sedangkan sirkulasi mengacu pada pergerakan barang. Proses ini menengahi antara momen-momen 'produksi dan konsumsi' dalam perekonomian.

Antropologi ekonomi telah mengembangkan tipologi bentuk distribusi yang awalnya diusulkan oleh polayi. Distribusi polayi adalah elemen yang menyediakan kontinuitas dan struktur untuk proses ekonomi, ia menyimpulkan tiga bentuk utama distribusi digunakan untuk mengintegrasikan ekonomi: timbal balik redistribusi, dan pertukran, tipologi ini mengungkpakn kelembagaan tidak begitu banyak transaksi.

3) Konsumsi dapat didefinisikan secara sederhana sebagai penggunaan barang atau jasa. Penggunaan terkadang menyiratkan penghancuran barang dan menghalangi penggunaaan lebih lanjut; jika tidak, suatu barang dapat digunakan dalam bebagai cara, berturut-turut atau bersamaan oleh orang yang berbeda

Antropologi ekonomi berfokus pada hubungan social yang muncul melakui proses konsumsi di ruang rumah tangga atau ruamg publik lain yang lebih terbuka.beberapa antropologi menggaris bawahi aspek bermakna dari tindakan konsumsi yang yang dipahami sebagai tanda-tanda dlam sisitem informasiyang mengekprsikan hubungan social.

2. Tema Inti dalam Antropologi Ekonomi. Chris Haan.2018

a. Mata Pencarian

Salah satu cara untuk mengatur pengetahuan dalam antropologi ekonomi, yang berasal dari era ketika pendekatan evolusionis mendominasi dan bertahan paling kuat dalam subbidang lingkungan (rkologis) dari disiplin tersebut, adalah dengan mengklasifikasikan masyarakat menurut cara utama yang digunakan anggotanya untuk memperoleh penghidupan, baik secara langsung untuk penghidupan atau untuk mendapatkan uang dalam ekonomi tunai dengan membuang surplus meraka, atau kombinasi keduanya. Ensiklopedia ini berisi tentang pemburu, pengumpul,pengembala, hortikultura, petani, perikanan, pertambangan, sector informasi, dan pekerja industri. Kategori-kategori ini menandai subbidang yang cukup koheren di mana para antropologi merasa terbantu untuk membedakan pola perilaku ekonomi dan mengeksplorasi interaksi dengan dimensi lain dari kehidupan social manusia, teknologi, dan lingkungan ekologis. 
b. Kerja

Cara alternatif untuk menyusun bidang antropologi ekonomi adalah meminjam dari pengklasifikasi dasar ekonomi seperti produksi,konsumsi, distribusi,pasar, kredit, investasi,dan sebagainya, ini adalah istilah prgadigma Barat. Dan harus berhati-hatiuntuk menyesuaikan kekika menerpkannya dalam konteks non-Barat. Tetapi asalkan seorang tetap sadar aka nasal usulnya, tidak salahnya dilakukan dengan cara ini. Sebagian besar kelompok manusia memiliki beberap istilah yang mungkin kita terjeemahkan sebagai "pekerjaan”. Dalam arti aktivitas yang diarahakan pada tujuan yag berbeda dari suatu yang mendekati permainan atau waktu.

c. Konsumsi

Studi konsumsi diabaikan untuk sebagian besar sejarah antropologi ekonomi, ia menjadi terkenal pada akhir abad kedua puluh ketika debat formalis-substantivis telah mereda dan pendekatan neo-Marxis telah ditolak karena dugaan determinisme ekonomi mereka. Jika konsumsi diidentikkan secara luas dengan reproduksi social, maka bisa dibilang itu telah menjadi pusat penelitian antropologi sejak awal dimana istilah kekerabatan klasifikasi memetakan alam semesta social dapat dilihat sebagai setara dengan cara dimana sistem harga mengintgrasikan ekonomi yang dimonetisasi. Para antropologi telah memebrikan kontribusi studi perintis tentang perubahan historis dalam pola konsumsi yang menyoroti muncunya masakan haute yang berbeda dengan di zaman perunggu. Antropologi telah memperhaitkan estetika dan budaya material, dan peran konsumsi dalam mengekpresikan identitas kolektif, dari kelompok etnis hingga subkultur muda.

d. Perdagangan dan pasar

Perdagangan dan pasar membentuk landasan utama di mana kaum substantif, yang dipimpin oleh Polanyi, mengajukan tantangan mereka kepada kaum formalis pada 1950an dan 1960-an. Mereka berpendapat bahwa perdagangan yang dimotivasi oleh keuntungan, seperti yang diteorikan oleh Adam Smith, bukanlah cara utama di mana perdagangan telah berkembang sepanjang sejarah. Perdagangan jarak jauh, diatur melalui politik, diplomasi, dan administrasi kontrol, adalah sering lebih signifikan. Antropolog ekonomi merasa perlu untuk menyelidiki konteks sosiokultural ekonomi kapitalis yang kompleks dan hubungan sosial yang membentuk setiap tindakan pertukaran. Keith Hart (2000). 
e. Uang dan barter

Topik kunci lain bagi para antropolog ekonomi sejak awal adalah uang. Marcel Mauss berpendapat untuk definisi yang lebih luas yang akan mencakup (barang-barang berharga dari para Trobriand Kepulauan),. Polanyi lebih eksplisit dalam menantang para ekonom bersumsi bahwa uang muncul dalam rangka untuk menyelesaikan ifesiensi pertukaran barter. barter perlu dilihat lebih dari pertukaran dari yang diinginkan komoditas; itu biasanya memiliki sebuah kaya budaya dan diplomatik konteks. Keith Hart (2000)

Salah satu tugas antropologi ekonomi adalah menyusun klassifikasi-klasifikasi sistem ekonomi di dunia, termasuk di dalamnya klasifikasi pertukran (Dalton, 1961:16). Polayi (1968) merupakan salah satu seorang sarjana yang mencoba merinstis klasifikasi pertukaran, dia membdakan pertukaran menjadi tiga pola, yaitu: resiprositas, redistribusi,dan pertukaran pasar pertukran tersebut didasarkan pada harapan-harapan atau motif yang ingin diperoleh para partisipan dalam melakukan transisi.

Menurut Polayi (1968). Resiprositas dan redistribusi merupakan pola pertukaran dalam sistem ekonomi sederhana, sedangkan pertukran pasar merupakan merupakan pola dalam dalam sistem ekonomi pasar

f. Kredit dan Hutag.

Hutang adalah tema mapan lainnya dalam antropologi ekonomi, khususnya dalam konteks patani dan sistem perdagangan dan pasar non industri di mana hubungan kepercayaan selalu menjadi pusat. Utang mungkin terkait dengan investasi produk, tetapi juga terkait dengan hubungan esksploitatif. Kredit dan hutang telah lebih menonjol dlam antropologi ekonomi dengan krisis global awal abad kedua puluh satu. Antropologi telah mengeksplorasi finansialisasi di banyak tingkatan, dari lembaga pusat hingga skema keungan mikro yang dimaksudkan untuk mengentaskan kemiskinan di dunia selatan. Dalam kondisi tertentu, bagaimanapun, kebijakan untuk mempromoskan "inklusi keuangan" dapat memiliki konsekuensi yang menguntungkan.

g. Globalisasi

Para antropologi ekonomi berusaha keras untuk menempatkan studi etnografi meraka dalam dinamika global, khususnya dinamika imperialis ekslitatif kapitalisme sebagai sistem dunia. Melengkapi laporan tingkat makro, studi konsumsi telah menarik perjatian pada acara-cara di mana produk global dan modernitas itu sendiri mengalami apropriasi local. Proses pelokalan ini semakin didorong oleh kebijakan perushan 
transnasional yang cerdas. Periklanan dan brending sangat penting untuk pemasaran yang sukses.

h. Sosialisme

Banyak antropologi menjelajahi organisasi ekonomi khas Negara-negara sosialis di manapun dimungkinkan untuk mendapatkan akse ke sana. Sebagian besar pekerjaan di Eropa bagian Timur berbasis pedesaan dan terkonsentrasi pada pertaniankolektif. Studi menunjukkan bahwa adaptasi yang lebih berhasil ari doktrin perencanaan pusat seprti yang dikembangkan di Hongaria selatan 1968, adalah yang menggabuangkan prisnsip kepemilikan social dengan insentif material dan sinyal pasar. Studi pabrik menunjukkan bahwa maslah keterasingan dan ekspoitasi mungkin tidak begitu berbeda dari maslah yang dikemukakan di pabrik kapitalis, (mislanya sistem upah borongan yang digunakan) Namun, satu-satunya model umum sosialis yang dikembangkan oleh seorang antropologi didasarkan pada kasus Rumania, varian yang sangat represif dibawah kediktatoran.

i. Ekonomi moral

Ekonomi moral adalah bidang yang sangat penting yang telah lama menjadi perhatian para antropologi ekonomi, khususnya yang dibangun berdasarkan penggunaan konsep oleh sejarawan Marxis E.P. Thompson dan ilmuan politik. Ekonomi arus utama cendrung mendekati kesejahteran dengan focus pada Pareto Optimon (kondisi dimana tidak ada penyimpangan yang dapat dilakukan tampa mengurangi utilitas orang lain) tetapi distribusi awal ini tidak ada hubungannya dengan keadilan normative. Mereka yang menyerukan ekonomi moral biasanya berfokus pada norma dan nilai kelompok yang bersangkutan, terutama kemampuan kelas bawahan untuk menegaskan norma-norma tersbut sebagai bentuk protes dan perlawanan.

j. Rumah Tangga

Dalam versi antropologi ekonominya, polayi sebagaimana dikutip oleh Chris Hann, dia memasukkan "rumah tangga" sebagai bentuk integrasi kemapat (selain timbal balik, redistribusi, dan pertukaran), meskipun ini akhirnya dibatalkan (atau lebih tepatnya di masukkan kedalama katagori redistribusi), studi tentang cirikhas kehidupan ekonomi pada tingkat ini telah menjadi kompoenen utama antropologi ekonomi sajak awal terinspirasi oleh ekonomi agraia. Para antropologi menyadari bahwa dinamika produksi dalam ekonomi petani yang terutama berorientasi pada pemenuhan kebuthan subsisten anggotanya akan berbeda dari dinamika produksi kapitalis. Chris Hann. 2018. 
3. Struktur dan Perilaku Ekonomi

Dalam sintesa antropologi ekonomi mengruaikan terdapat 3 pradikma yang berbeda yang di gunakan antopologi ekonomi untuk memahami struktur dan perilaku ekonomi, yaitu :

a. Model Sosial-struktur dan politik ekonomi

Model social focus pada kelompok, perhatian disiplin standar para antropolog. Mereka mulai dari asumsi bahwa manusia adalah social; mereka hidup dan bertindak ddalam kelompok, yang struktur dan nilainya membatasi pilihan dan tindakan individu. Dalam model social, baik ekonomi maupun masyarakat bukanlah kumpulan prilaku individu, tetapi sesatu yang lebih besar dengan logika dan aturannya sendiri. Ada dua jenis utama model social, yaitu:

1) Model social-struktural didasarkan pada karya emile Durkheim, yang melihat kehidupan social sebagai sumbe harmoni kekuatan, masyarakat manusia bergantung pada kerja sama, yang pada gilirannya menurut penekanan kepentingan pribadi dalam tunjuk kelompok. Nilai-nilai masyarakat, yang dibentuk dan diperkuat melalui interkasi manusia, meningkatkan kondisi yang mempertahankan keadaan masyarakat. Dengan demikian sistem social yang berhasil ada dalam keseimbangan yang mengutamakan pelestarian perubahan.

2) Model politik-ekonomi didasarkan pada Kal Marx, yang berfokus pada konflik kepentingan social. Dalam model ini, sumber dasar komflik adalah distribusi kepmilikan pribadi yang tidak merata antar kelas. Ketimpangan terstruktur melalui cara produksi, yang menfasilitasi atau membatasi akses ke sumber daya, termasuk tanah, tenaga kerja, dan modal. Karena kelas social adalah bentuk utama diferensiasi dalam masyarakat, perjuangan potitik atas distribusi sumber daya dan kekauasaan terjadi antar kelas.

b. Model Kepentingan Sendiri

Dalam model kepentingan sendiri, fokusnya adalah pada individu sebagai pembuat keputusan rasional yang mengalokasikan sumber daya menakut-nakuti untuk tujuan alternatif. Ini tumpang tindih secara substansial dengan pendekatan ekonomi micron kontemporer. Dalam model ekonomi kontemporer, tujuan utamanya adalah utlitas, segala sesuayu yang membawa kepuasan bagi seorang individu. Meskipun ekonom kontemporer mengakui bahwa utilitas tidak sama dengan uang, mereka sering mengukurnya dalam istilah moneter.sebaliknya, antropolog lebih cendrung melihat tujuan lain yang dicita-citakan orang, terutama dalam masyarakat dimana transaksi 
ekonomi tidak dimediasi oleh uang atau sistem pasar. Namun, meskipun mungkin tujuannya berbeda, individu tetpa dianggap sebagai pembuat keputusan rasional yang membuat keputusan.

c. Pradigma ketiga adalah model ekonomi budaya, yang berusaha memahami ide-ide dan nilai-nilai yang memotifasi tindakan orang, termasuk inovasi. Ekonom budaya focus pada budaya sebagai komonikasi simbolik dan sistem makna. Dalam antropolog komtempore, model budaya ditemukan terutama dalam antropologi intrepretatif, yang menarik perhatian pada nilai-nilai dan sistem simbolik sebagai landasan makna dan tindakan.

Penggunaan model budaya dapat mengarah pada perspektif yang ingin dilawan oleh model kepentingan pribadi, seprti gagasan bahwa nilai-nilai budaya menghalangi pemikiran strategis dan inovatif. Mislanya model budaya telah mengarah pada konsep budaya kemiskinan, yang mengsulkan bahwa nilai-nilai orang miskisn meningkatkan kemiskinan mereka. Ini mengsulkan dan mengembangkan ide iniyang menghubungankan budaya kemiskinan dngan kondisi material dan social dimana orang miskin tinggal.

\section{Masa Depan Antropogi Ekonomi}

Pada tahun 1950 an tidak mungkin untuk memprediksi sebagian besar topic dipejalari oleh antropologi ekonomi. pada tahun 200 an, mislanya, topic baru telah muncul, seperti "branding" dan "hibriditas", serta metodologi esksperimental bar. Demikain pula, hari tidak mungkin untuk memprediksi topic penelitian antropologi ekonomi 50 tahun kedepan. Bahkan akan sulit untuk mengantisipasi 10 tahun kedepan! Namun demikian, ada beberapa peluang yang membuka peluang globalisasi ekonomi yang cepat bagi antropologi ekonomi. Komintas internet yang semakin popular dan jejaring social virtal mewakili normal social, diskriminasi, gerakan politik, dan banyak topok lainnya dapat dianalisis melalui "antropologi virtual". Faktanya, dunia virtual mendefiniskan ulang sifat menjadi partisipasi pengamat. Andres. 2010

\section{KESIMPULAN}

Antropologi ekonomi awalnya hanya berfokus pada kehidupan Ekonomi Masyarakat Primitf, di mana banyak elemen yang ada dalam ekonomi barat. Namun stelah melalui perdebatan dan teori ekonomi sdh banyak yang muncul antropologi ekonomi mengakui adanya keterkaiatan antara antara antropolgi dan ekonomi. terdapat beberpa poin yang tidak bisa lepas dari antropologi ekonomi yaitu tentang pencaharian, kerja, produksi, konsumsi, distribusi, perdagangan pasar, uang dan barter, kredit dan hutang, globalisasi, sosialisme, ekonomi moral dan rumha tangga bahkan 
dalam antropologi ekonomi untuk melihat struktur dan peilaku ekonomi menggunakan tiga pradigma yang berbeda, yaitu: modek social-struktur dan politik ekonomi yang fokusnya terhadap kelompok-kelopok yang terdapat dalam masyarakt, selanjutnyan model kepentingan sendiri yang fokusnya pada individu sebagai pembuat keputusan rasional,kemudian yang terahir model ekonomi budaya, yang fokusnya berusaha memahami ide-ide dan nilai-nilai yang memotifasi tindakan orang. 


\section{DAFTAR PUSTAKA}

Cook, Scott. 1973. "Ekonomic Antropologiy: Problem in theory, method and analisi”, dalalm John J. Honingman (ed), Handbook of Social and Cultural Anthropology. New York: Company Inc.

Anthropology, American University, Washington, DC, USA

Dalton George Brad college,1961 Economic Theory And Primitif Society. Amireican Anthropologist.

Hann, Chris, 2018. Economic Athropology, The International of Anthropology. Editet By Hilary Callan. John Willy \& Sons, Ltd

Jacob, Teuku. (2006). Manusia Makhluk Gelisah, Melalui Lensa Bioantropologi. Surakarta: Muhammadiyah University Press.

Keit, Hart,. 2000. The Memory Bank: Uang di sebuah merata Dunia . London: Profil

Koenig, Dolores, Development and Economic Anthropology: The Contributions of EconomicAnthropology to International Development Practice - Department of

leClair, Edward E. JR. dan H.K.Schneider. 1968. " The Development of Ecomic Anthropology", dalam Edwad E. LeCair JR. dan H.K.Schneider (ed). Economic Anthropology, Reading in Theory And Analysis. New York : Holt, Renehat andWindon. In.

Muhammad, Nurazzura diah \& Mahboob, Dewan Hossain,2014. An Overviw of the Anthropologycal Theories. Intenasional Journal of Humatities and Social Scaience, vol 3. No 10 (1) Agustust

Morgan, M.S Morgan \& Qin D. Eksiklopedia Internasional Ilmu Sosial \& Perilaku

Marquen, Andres Gramajo.2010 Economic Antropology Pas And Future. Jornal Laissez-and Fair, no 32

Polanyi dan kalr 1968, sosietis and economic system” dalam Geoge Dalton, (ed). Primitive,arabiv and moderan. Essyas of karl polayi .boston. beacon press.

Ronald, Frankemberg. 1975. “Economic Anthropology : One An-thopology’s view”. Dalam R. Fitert, Themes inEconomic Anthropology, London: Tavisttoc Publication

Tabrani, Islamic Studies dalam Pendekatan Mulitidisipliner (Studi Kajian Gradual Menuju Pradigma Global) Jurnal PEURADEUN : Media Kajian Ilmiah Sosial, Poitik,Hukum, Agama dan Budaya

Williiam, Haviland, A. (1988). Antropologi. Peterj: RG Soekarjo, Jakarta: Erlangga.

George, Dalton, 1961. Economic Theory and Primitif society”. Amirican Antropologi. 63 (1) 